\title{
Parental exposure to environmental concentrations of diuron leads to aneuploidy in embryos of the Pacific oyster, as evidenced by fluorescent in situ hybridization
}

\author{
Barranger Audrey
${ }^{1,2, *}$, Benabdelmouna Abdellah
Akcha Farida
${ }^{1 *}$
}

${ }^{1}$ Ifremer, SG2M, Laboratory of Genetics and Pathology of Marine Molluscs, Avenue de Mus du Loup, $17390 \mathrm{La}$ Tremblade, France

2 Ifremer, Department of Biogeochemistry and Ecotoxicology, Laboratory of Ecotoxicology, Rue de l'lle

d'Yeu, BP 21105, 44311 Nantes Cedex 03, France

* Corresponding author: Audrey Barranger, tel.: +330546762632 ; fax: +330546762611;

email address : audrey.barranger@ifremer.fr

\begin{abstract}
:
Changes in normal chromosome numbers (i.e. aneuploidy) due to abnormal chromosome segregation may arise either spontaneously or as a result of chemical/radiation exposure, particularly during cell division. Coastal ecosystems are continuously subjected to various contaminants originating from urban, industrial and agricultural activities. Genotoxicity is common to several families of major environmental pollutants, including pesticides, which therefore represent a potential important environmental hazard for marine organisms. A previous study demonstrated the vertical transmission of DNA damage by subjecting oyster genitors to shortterm exposure to the herbicide diuron at environmental concentrations during gametogenesis. In this paper, Fluorescent in situ hybridization (FISH) was used to further characterize diuron-induced DNA damage at the chromosomal level. rDNA genes (5S and 18-5.8-28S), previously mapped onto C. gigas chromosomes 4,5 and 10 , were used as probes on the interphase nuclei of embryo preparations. Our results conclusively show higher aneuploidy (hypo- or hyperdiploidy) level in embryos from diuron-exposed genitors, with damage to the three studied chromosomal regions. This study suggests that sexually-developing oysters are vulnerable to diuron exposure, incurring a negative impact on reproductive success and oyster recruitment.
\end{abstract}

\section{Highlights}

FISH was realized on oyster embryos from diuron-exposed genitors. rDNA genes were used as probes on the interphase nuclei of embryo preparations. Higher aneuploidy level was observed in embryos from diuron-exposed genitors. Hypo- and hyperdiploid (triploid) nuclei were detected.

Keywords : Aneuploidy, FISH, Diuron, Crassostrea gigas 


\section{INTRODUCTION}

Cells characterized by the loss or gain of one or more whole chromosomes in comparison to the normal haploid or diploid condition are considered as aneuploid. Aneuploidy is the most common genetic defect in humans and somatic aneuploidy has been linked to the development of various cancers (Kops et al., 2005; Weaver and Cleveland, 2006). Germinal aneuploidy can have major detrimental effects, as it impacts the following generation, resulting in mental retardation, congenital malformation and miscarriage. When all classes of numerical chromosomal abnormalities (monosomy, trisomy, polyploidy) are taken into account, these abnormalities are thought to contribute to more than half of all spontaneous abortions; aneuploidy is thus considered as the major cause of reproductive loss in man (Aardema et al., 1998; Abruzzo and Hassold, 1995; Hassold and Hunt, 2001).

Changes in normal chromosome numbers due to abnormal chromosome segregation may arise spontaneously (age, genetic instability, etc.), or as a result of chemical/radiation exposure, particularly during cell division. Several chemicals are known to induce aneuploidy in vitro or in animals in vivo. The marine environment and, in particular, coastal ecosystems, are continuously subjected to various contaminants, originating from urban, industrial and agricultural activities. Certain contaminants exert their effects via genotoxic mechanisms, simultaneously causing embryotoxicity, carcinogenesis and long-term damage to organisms (Jha et al., 2000). Among these chemicals, phytosanitary products are a major concern in France, which is the leading user of agrochemicals in Europe and the third-biggest user worldwide (Jacquet et al., 2011; UIPP, 2012). During rain events, pesticides can be drained by catchment areas and contaminate coastal waters, hence creating an environmental risk for aquatic organisms. The bio-ecological particularities of marine bivalves (filter feeders, sessile mode of life and ability to bioaccumulate 
pollutants) make them particularly sensitive to chemical stress, which can lead to reversible or irreversible genomic abnormalities such as DNA breaks or chromosomal aberrations. The relationship between genotoxicity and pollutants or polluted environments has been wellinvestigated in marine invertebrates and in particular in oysters and mussels (Akcha et al., 2012; Bihari et al., 2003; Dallas et al., 2013; Marcheselli et al., 2011; Wessel et al., 2007). Moreover, the parental transmission of DNA damage has already been demonstrated, although the associated literature is incomplete (Barranger et al., 2014; Bouilly, 2004). The consequences of genomic abnormalities induced by chemicals on animal fitness are of major interest for understanding the long-term impact of genotoxic pollutants on wildlife.

Regarding the Pacific oyster, high mortality phenomena have been observed in summer in many regions of the world, in particular on French coasts (Samain et al., 2007). In most cases, summer mortality is not allocated to a single factor, but a combination of several parameters, including physiological stress, environmental conditions and pathogenic organisms (Dégremont et al., 2010; Huvet et al., 2010; Renault et al., 1994; Samain et al., 2007). As many oyster production areas are subject to anthropic pressures, in particular pesticides inputs (Burgeot et al, 2008; Munaron et al., 2003), the possible role of environmental pollution in oyster mortality events is being increasingly examined in France and elsewhere (Ochoa et al., 2012). Understanding this phenomenon is a complex but very important challenge, as the Pacific oyster, Crassostrea gigas, is one of the foremost aquaculture resources worldwide (FAO, 2012) and France is currently Europe's leading producer. This species, whose diploid chromosome number is 20 ( $2 n=2 x=20$ chromosomes), can tolerate a genome size variation of between 5 and $15 \%$ (DNA aneuploidy) and a percentage of hypodiploid cells with 17, 18 or 19 chromosomes varying from 5 to over 30\% (Benabdelmouna et al., 2011; Leitão et al., 2001b; Thiriot-Quiévreux et al., 1992; Zouros et al., 1996). Various methods are available for characterizing these genomic 
abnormalities. Originally, cytogenetic analysis could only be performed by conventional karyotyping. However, this approach is technically demanding, time-consuming and limited by the number of metaphase cells available for analysis. Additionally, poor chromosome preparations and frequent artifactual variations in chromosome numbers may compromise results. These limitations can be overcome by recent molecular cytogenetic techniques as Fluorescent In Situ Hybridization (FISH), allowing chromosome and gene identification, not only onto metaphase preparations but also starting from the more accessible material represented by interphase nuclei (I-FISH). This method has essentially been used in higher vertebrates, such as human, equine, bovine and porcine cells (examples in embryo nuclei: Rambags et al., 2005; Viuff et al., 2002; Zudova et al., 2003). FISH analysis has already been used for the chromosome characterization and identification of bivalves (Benabdelmouna et al., 2008; Cross et al., 2005; Wang et al., 2004; Xu et al., 2001), but never previously for the detection of genomic abnormalities in ecotoxicological studies.

In a previous experiment, the vertical transmission of DNA damage was highlighted by exposing oyster genitors to short-term environmental concentrations of diuron - a substituted urea herbicide used for on-land weed control - during gametogenesis (Barranger et al., 2014). In spat from diuron-exposed genitors, a significant decrease in nuclear DNA content was measured, with over $15 \%$ of individuals showing DNA hypodiploidy, i.e. a decrease in their genome size relatively to eudiploid oysters.

In this study, rDNA probes were hybridized on interphase nuclei (I-FISH) from embryos produced by controls and diuron-exposed oyster genitors in order to supplement information on the aneugenic effects of diuron. These genes were chosen to specifically label particular chromosomes and identify their numerical variations. The major (18-5.8-28S) and minor (5S) rRNA genes used in our study are two families of ribosomal RNA genes in higher eukaryotes. 5S 
ribosomal RNA is the smallest RNA component of the ribosome. Both genes are organized into clusters of tandem repeats with up to hundreds or thousands of units (Martins and Galetti, 2001). In view of their high copy number, rRNA genes can easily be detected by FISH and used for chromosome identification (Fontana et al., 2003; Insua et al., 2001; Liu et al., 2003).

There are a number of advantages to studying freshly-fertilized embryos. Firstly, the cells are in an active state of division; this is an ideal state for studying aneugenic effects leading to chromosome loss or gain, allowing adverse effects to be observed prior to cell death or removal of the aberration through DNA repair. Moreover, the study of early life-history stages provides various information on population fitness.

\section{MATERIALS AND METHODS}

\subsection{Genitor origin, diuron exposure and fertilization}

The adult Pacific oysters (Crassostrea gigas) used for this experiment were the progenies of wild oysters sampled in the Marennes-Oléron Bay (France). One hundred oysters were spawned in February 2011 at the Ifremer hatchery, to produce 6 batches, each cross using around 16 parents. These 6 batches were then mixed at the juvenile stage to get one group, in order to limit any batch effect. The resulting group of oysters was used for this experiment.

Oyster husbandry, diuron exposure and fertilization were performed as described in Barranger et al. (2014). Briefly, following a one-month acclimatization period, sea water temperature $\left(8^{\circ} \mathrm{C}\right.$ $\left.\pm 1^{\circ} \mathrm{C}\right)$ was gradually raised by two degrees per day for 1 week, to reach $19.8^{\circ} \mathrm{C}\left( \pm 0.3^{\circ} \mathrm{C}\right)$. Once gonad development had begun, the oysters were divided into three experimental groups: a seawater control, a solvent control and a diuron-exposed group. Diuron - the pesticide selected for our study - is a substituted urea herbicide used in agriculture for on-land weed control. This 
herbicide is also used as an antifouling biocide (Thomas et al., 2001). In France, it has been banned as phytosanitary product since 2008 (JO no. 204 September 4, 2007), and as biocide used in antifouling paints since 2009 (bylaw 28 August, 2008). Although data on pesticide transfer from the continent to French coastal ecosystems is fairly rare, recent studies have reported the presence of diuron in various French aquatic environments (Atlantic bays, estuaries and Mediterranean Sea) (Buisson et al., 2008; Caquet et al., 2013; Munaron et al., 2012, 2006). As diuron stock solution is sold in acetonitrile, the solvent control group was exposed to acetonitrile at a concentration of $0.005 \%$. This concentration of acetonitrile has already been used in a previous study of Akcha et al. (2012) and did not reveal any genotoxic and embryotoxic effects on spermatozoa or embryo, respectively. Three $250-\mathrm{L}$ tanks were used for each experimental group, containing each 240 oysters. Two 7-day exposure periods took place at the start and midcourse of gametogenesis, during which the oysters were exposed to 0.4 and $0.6 \mu \mathrm{g} / \mathrm{L}$ of diuron, respectively. These short exposure pulses were chosen to mimic rain events with concentrations of diuron close to those detected in coastal waters (see Barranger et al., 2014 for details).

Within experimental group, when oysters were ripe, males and females ( $\mathrm{n}=70$ oysters per group) were individually induced to spawn through thermal shocks (from $18^{\circ} \mathrm{C}$ to $28^{\circ} \mathrm{C}$ for 30 min). The oocytes were then pooled within group, as well as the spermatozoa, and the fertilization was achieved using 9,000,000 oocytes and a ratio of 200 spermatozoa per oocyte.

\subsection{I-FISH analysis}

Embryonic nuclei preparation. Four hours after fertilization, developing embryos were collected and transferred to a hypotonic solution ( $0.9 \%$ sodium citrate) for $15 \mathrm{~min}$. Following 
incubation in the latter solution, the embryos were recovered and fixed twice for $20 \mathrm{~min}$ in a freshly-prepared $100 \%$ ethanol:glacial acetic acid (3:1) solution and stored at $-20^{\circ} \mathrm{C}$ pending use. For nuclei preparation, the embryos were recovered by centrifugation and transferred to $45 \%$ acetic acid for cell dissociation. Microscopic preparations were then obtained by dropping nuclei onto pre-warmed microscope slides at $44^{\circ} \mathrm{C}$ and dried overnight prior to $\mathrm{FISH}$ analysis.

DNA probes. Probes targeting 5S rRNA genes and 18-5.8-28S rRNA genes were selected for our study; these genes had already been mapped on C. gigas chromosomes in previous studies. In C.gigas, the major ribosomal RNA genes (18-5.8-28S) are located in the long arms of chromosome 10 (confined to the telomere region), which is the shortest chromosome (Xu et al., 2001). 5S rRNA genes are located in an interstitial position, on two different chromosome pairs: a major site on chromosome 4 and a minor site on chromosome 5 (Benabdelmouna et al., 2008). C. gigas 5S rDNA was obtained by PCR amplification of total genomic DNA in the presence of 5S-specific primers, as described by Cross et al. (2005). The obtained PCR fragments were cloned and labelled by digoxigenin-11-dUTP using nick translation (Benabdelmouna et al., 2008). Two recombinant plasmids (HM123, HM456) were used for the 18S-5.8S-25S rDNA probe, containing fragments of Xenopus laevis rDNA (Meunier-rotival et al., 1979) combined in a probe mix. This probe mix was labelled using nick translation by direct incorporation of tetramethylrhodamine-6-dUTP.

In situ hybridization. The in situ hybridization reaction was accomplished as described in Benabdelmouna and Abirached-Darmency (1997), with slight modifications. The hybridization mixture was prepared to a final concentration of $5 \mathrm{ng} / \mu \mathrm{L}$ digoxigenin and tetramethylrhodaminelabelled probes in 2X SSC, 10\% dextran sulfate, $0.1 \%$ SDS, 1 mM EDTA, $1 \mathrm{X}$ Denhardt's and 
$50 \%$ deionized formamide. Slides were incubated with $150 \mu \mathrm{L}$ of Rnase A $(100 \mu \mathrm{g} / \mathrm{mL}$ in $2 \mathrm{X}$ SSC) for 60 min at $37{ }^{\circ} \mathrm{C}$ under a plastic coverslip in a humid chamber. After 3 x 5 min washes in $2 \mathrm{X} \mathrm{SSC}$ and $2 \mathrm{~min}$ in $\mathrm{HCl} 10 \mathrm{mM}$ at room temperature, the slides were incubated with $150 \mu \mathrm{L}$ of pepsin solution $(50 \mu \mathrm{g} / \mathrm{ml}$ in $10 \mathrm{mM} \mathrm{HCl})$ for $10 \mathrm{~min}$ at $37^{\circ} \mathrm{C}$. After a 5 min wash in PBS $1 \mathrm{X}$, the nuclei preparations were then fixed in 1\% paraformaldehyde (in PBS 1X) for $10 \mathrm{~min}$ at room temperature, rinsed for 5 min in PBS 1X, dehydrated in 70, 95 and 100\% (v/v) ethanol and airdried. The hybridization mixture was denatured at $100{ }^{\circ} \mathrm{C}$ for $10 \mathrm{~min}$ and immediately quenched in ice for $5 \mathrm{~min}$, and $20 \mu \mathrm{L}$ were then pipetted onto each slide. A plastic cover slip was applied to the preparation and sealed with rubber solution. The nuclei and hybridization mixture were denatured at $80^{\circ} \mathrm{C}$ for $10 \mathrm{~min}$, and incubated overnight at $37^{\circ} \mathrm{C}$ in a humid chamber.

Following hybridization, the rubber solution was peeled off and the cover slips were removed by dipping the slides into $2 \mathrm{XSSC}$. The slides were then washed in three baths of $2 \mathrm{XSSC}, 0.5 \mathrm{X}$ SSC and 0.1X SSC for 10 min each at $42{ }^{\circ} \mathrm{C}$ and finally in $2 \mathrm{X} \mathrm{SSC}$ for $10 \mathrm{~min}$ at room temperature. The slides were then blocked with $200 \mu \mathrm{L}$ of TNB Buffer (100mM Tris-HCl (pH 7.5), $150 \mathrm{mM} \mathrm{NaCl}, 0.5 \%$ blocking reagent) for $30 \mathrm{~min}$ at $37{ }^{\circ} \mathrm{C}$. The blocking solution was drained off and the slides incubated with sheep Anti-digoxigenin-fluorescein antibody $(2 \mu \mathrm{g} / \mathrm{mL}$ in TNB) for $30 \mathrm{~min}$ at $37^{\circ} \mathrm{C}$ in a moist chamber. After $2 \times 5$ min washes in TNT Buffer (100mM Tris- $\mathrm{HCl}(\mathrm{pH} 7.5), 150 \mathrm{mM} \mathrm{NaCl}, 0.05 \%$ Tween 20 ) at $37^{\circ} \mathrm{C}$, the slides were incubated with fluorescein isothiocyanate (FITC)-conjugated rabbit anti-sheep antibody $(2 \mu \mathrm{g} / \mathrm{mL}$ in TNB) for 30 min at $37^{\circ} \mathrm{C}$. The final washes were performed with TNT Buffer for $2 \times 5$ min at $37^{\circ} \mathrm{C}$ in the dark. The slides were then dehydrated in 70, 95 and 100\% (v/v) ethanol and air-dried.

The nuclei were counter-stained with $1 \mu \mathrm{g} / \mathrm{mL}$ of 4',6-diamidino-2-phenylindole (DAPI) in VECTASHIELD medium (Vector Laboratories), covered with cover slips and stored at $4{ }^{\circ} \mathrm{C}$ for 1 day to stabilize fluorescence. Nuclei preparations were analyzed using a Zeiss axioplan 2 
imaging epifluorescent microscope equipped with appropriate fluorescent filters. Around 700 nuclei were analyzed for each experimental group (Table 1).

\section{Scoring criteria}

Only intact and non-overlapping embryonic nuclei were scored. Spots found in close proximity to each other were counted as one signal.

\subsection{Statistics}

Statistical tests were performed using STATISTICA (StatSoft, Inc.,version 10). An independent $\chi^{2}$ test was used to compare the number of nuclei across the different experimental groups. The significance level was set at $\mathrm{p}<0.05$.

\section{RESULTS AND DISCUSSION}

This study provided a first estimate of the basal frequency of spontaneous aneuploidy on the identified chromosomes in 4hr-old embryos of C.gigas. A total of 707, 712 and 662 nuclei were analysed for the seawater control, solvent-exposed and diuron-exposed groups, respectively. In embryos originating from the seawater control group, FISH analysis revealed cell nuclei predominantly showing (89.53\%; Table 1) 4 signals for 5S rDNA probe (two for chromosome pair 4 and two for chromosome pair 5) and 2 signals for 18-5.8-28S rDNA probe (chromosome pair 10), i.e. consistent with the typical diploid nucleus pattern (Figure 1, A). Otherwise, aneuploid nuclei represented a significant proportion of the analysed nuclei, among which $6.64 \%$ were hypoploid, $1.28 \%$ hyperploid (among which $0.57 \%$ were triploid) and $2.55 \%$ haploid (or hypoploid) (Table 1). The FISH patterns of embryos obtained from solvent-exposed genitors were essentially similar to those of embryos from the seawater control group. Indeed, $86.10 \%$ of the nuclei were diploid, $5.76 \%$ were hypoploid, $3.93 \%$ were hyperploid and $4.21 \%$ were haploid 
(or hypoploid) (see Table 1). However, the percentage of triploid nuclei $(2.95 \%)$ was higher in embryos from the solvent-exposed group versus the seawater control group. FISH patterns obtained in embryos from diuron-exposed genitors were significantly different $\left(\chi 2 ; \mathrm{p}<10^{-5}\right)$, with parental exposure resulting in an increase in genomic abnormalities in the descendants. Only $69.34 \%$ of the embryos from diuron-exposed genitors exhibited a typical diploid FISH pattern; the remaining nuclei were all aneuploid with differing ploidy levels: hypoploidy (17.82\%), hyperploidy (4.38\%), triploidy (3.02\%) and haploidy (8.46\%) (Table 1).

In seawater control group, our results support previous data published by Guo et al. (1992) using karyological analyses on Pacific oyster embryos. In the latter study, the authors found control Pacific oyster embryos to have a majority of cells $(89.30 \%)$ with a diploid number of 20 chromosomes, while spontaneous haploids, triploids and aneuploids accounted for $0.70 \%, 1.30 \%$ and $8.70 \%$, respectively. In our study, the frequency of aneuploids among controls was similar to the spontaneous level reported in other marine bivalves at the same development stage (for example: $8 \%$ for mussels in Dixon (1982); $8.7 \%$ for oysters in Guo et al. (1992)). This basal frequency of aneuploid nuclei could be explained by the fact that Pacific oysters, similarly to other marine bivalves, are known as r-strategist organisms, with a high ability to reproduce rapidly and high fecundity coupled with a low investment in gametogenesis quality, leading to the production of relatively high proportions of cytogenetically-abnormal germ cells.

In this study, chromosomes tagged by minor (5S) and major (18-5.8-28S) rDNA probes were affected by aneuploidy. Although both hypodiploidy and hyperdiploidy were observed in nuclei, hypodiploid nuclei were more frequent whatever the experimental group. Additionally, embryos from diuron-exposed genitors exhibited the higher level of aneuploid nuclei (Figure 1, B-L) and the most diversified FISH patterns (11 versus 5 in seawater control group), some of them being specific to diuron-exposed group (Figure 1, H-J). For chromosome 10, trisomy was detected in 
all experimental groups (Figure 1, B), but at a lower frequency than monosomy $(1.66 \%$ versus $6.64 \%$ in diuron-exposed group, for example) (Figure 1, C-E-K). For chromosomes 4 and 5, it's more difficult to identify monosomy or trisomy as minor and major site for 5S rDNA genes in nuclei cannot be clearly distinguished in interphase nuclei.

As oysters were exposed during gametogenesis, the predominant potential source of aneuploidy for embryos was gametes. In a previous study by Barranger et al. (2014), comet assay was performed on spermatozoa and a higher level of DNA strand breaks was detected on spermatozoa from diuron-exposed genitors. However, despite exhibiting high levels of DNA damage, male gametes still have the ability to fertilize eggs, potentially leading to the production of high levels of aneuploid embryos in the following generation. Indeed, in fish as well as in oyster, gynogenesis (all maternal inheritance) can be achieved even after the complete degradation of sperm DNA via irradiation (Guo et al., 1993; Komen and Thorgaard, 2007; Streisinger et al., 1981).

Various aneuploid formation mechanisms are known for gametes and in particular mammalian germ cells, e.g., the presence of translocations in the genome (Kirkpatrick et al., 2008). Another possible factor of aneuploidy is altered meiotic recombination, especially during M-phase, when spindles are forming and chromosome segregation occurs (Ferguson et al., 2007; Sun et al., 2008). This was a possible source of aneuploidy in our study, as the oysters were exposed to diuron during meiotic division. The improper segregation of chromosomes during meiosis can result in the production of genetically-unbalanced sperm or oocytes. If these gametes are involved in fertilization, the resulting embryo will be aneuploid, i.e. it will have too many chromosomes (trisomy), or too few (monosomy) as observed in our experiment.

A preliminary study reported the majority of aneuploids as being non-viable in the Pacific oyster (Guo et al., 1992). Indeed, as each chromosome contains hundreds of genes, the addition or loss 
of even a single chromosome will disrupt cell equilibrium and, in most cases, is incompatible with life (O'Connor, 2008). In this experiment, hatching rate was measured and a significantly lower rate was observed for offspring from genitors exposed to diuron $(42.4 \pm 5.9 \%$ versus 79.3 $\pm 10.8 \%$ and $76.7 \pm 12.1 \%$ for the seawater control and solvent control groups) (Barranger et al., 2014). The hatching rate in the control group was around $80 \%$, which appears to be in the expected range of values for oyster and other marine invertebrates (Bouilly et al., 2004; Pruski et al., 2009). It cannot be totally excluded that the presence of immature eggs could explain the $20 \%$ of hatching failure. However, unlike studies where gametes were collected after gonad stripping, it is noteworthy that in the present study gametes were obtained by thermal shock (natural spawning), ensuring expulsion of mature gametes. Moreover, histological analysis of oyster gonads done in each experimental group (unpublished data) confirmed that all oysters were at stage III, corresponding in $C$. gigas to mature reproductive stage (Berthelin et al., 2001). In diuron-exposed group, the percentage of embryos (around 60\%) that did not reach the Dlarvae stage could be affected by severe DNA damage as demonstrated by the higher level of aneuploidy detected by FISH. In the present study, major rDNA genes which are constitutive of the nucleolus have been shown to be affected by DNA damage, pointed out a possible disruption of the nucleolar structure. Instability such as DNA damage in rDNA genes could affect protein synthesis and cell functions, potentially resulting in the observed embryo development arrest. It could be the case for p53 which plays a central role in nearly all cell stress responses, including gene expression, DNA repair, cell cycle arrest, metabolic adjustments, apoptosis, and senescence (Elkholi and Chipuk, 2014). p53 is known to be regulated by nucleoli those function is directly dependent on its structure (Boyd et al., 2011). As a consequence, damage in rDNA genes could indirectly result in the activation of p53 leading to cell cycle arrest or apoptosis (Jin et al., 2014). 
Survival of aneuploid organisms is generally associated with negative physiological consequences. Indeed, in a natural population of C.gigas, Leitao et al. (2001a) demonstrated a significant negative correlation between aneuploidy and growth. Otherwise, Barranger et al. (2014) found larvae from diuron-exposed genitors to have lower growth and delayed metamorphosis, which may be directly linked to the genomic abnormalities. A global modification of gene copy numbers subsequently alters the expression of genes on the affected chromosomes, resulting in phenotypic changes (FitzPatrick et al., 2002). Therefore, DNA damage caused by pollutants could be responsible for a general lower fitness of $C$. gigas, leading to a higher sensitivity to stressors and contributing to the mortality outbreaks affecting C. gigas populations in France, particularly since 2008.

It is important to note that the two probes used in this study only detect three chromosomes $(4,5$ and 10) out of ten, and particularly two chromosomes (5 and 10), which are very prone to aneuploidy. Indeed, according to the results obtained by Leitão et al. (2001b), chromosome losses in C. gigas are not random but reflect differential chromosome susceptibility, in particular with regards to four chromosomes (pairs nos. 1, 5, 9 and 10) out of the ten affected by chromosome loss. It can therefore be concluded that the FISH results obtained on interphase nuclei only highlighted alterations affecting the labelled region and provided partial information on what was occurring inside the cell.

Triploid nuclei were observed in all of the experimental groups (Figure 1, L). As explained by Guo et al. (1992), spontaneous triploids have already been reported in other species of amphibians, fish and molluscs and are probably caused by the fertilization of unreduced gametes or by accidental blocking of the extrusion of one of the polar bodies (Fankhauser, 1945; Guo et al., 1992; Thorgaard and Gall, 1979). The percentage of triploids in the control group was low and similar to the basal level reported for this species (Guo et al., 1992). This triploid rate was 
higher when parents had been exposed to either the solvent or diuron. This is probably due to the fact that the chemicals used in our study (acetonitrile and diuron) can increase the production of unreduced gametes and/or affect the egg membrane during early fecundation steps, thus allowing polyspermy. This phenomenon has already been reported following exposure to chemicals such as cytochalasin B (Longo, 1972; Peaucellier et al., 1974; Stepto and Cook, 1998).

Nuclei considered as haploid (Figure 1, G) found in the different experimental groups could be due to sperm incorporation failure, leading to the production of gynogenetic haploid embryos. Frequency was higher in gametes from diuron-exposed genitors, suggesting a possible impact of diuron on fertilization. This latter effect has already been observed in C. gigas following sperm exposure to diuron concentrations as low as $0.04 \mu \mathrm{g} . \mathrm{L}^{-1}$ (Mai et al., 2013).

As reviewed in Vorsanova et al. (2010), I-FISH using site-specific DNA is a powerful technique which is usually used for diagnosing known microdeletion and microduplication syndromes, aneuploidy and recurrent chromosome abnormalities in Human. Nevertheless, this technique has several limitations. The first limitation of I-FISH using site-specific DNA is linked to hybridization and detection efficiency. As a matter of fact, hybridization efficiency of $70 \%$ is required at minimum for adequate analysis. In the present study, I-FISH using rDNA probes showed very high hybridization efficiency with all the nuclei being labeled. A second limitation is related to DNA replication during S-phase of cell cycle. Transcriptionally active nuclei could exhibit more than the normal number of signals and in this case these nuclei could be falsely interpreted as aneuploid, or polyploid. However, in such transcriptionally active nuclei, FISH signals are usually detected as small and diffuse fluorescent signals. It was not the case in the present study where additional hybridization sites were always detected as signals with similar and normal intensity. The last limitation of I-FISH that could lead to underestimate detected signals could be related to the structural tri-dimensional organization of the nucleus. This is 
particularly true for I-FISH using ribosomal genes which are constitutive of the nucleolar organizing region (NOR). In interphase nuclei, chromosomes with NOR cluster together in the nuclear space to form the nucleolus and are restrained from movement by their association with the nucleoli (Parada and Misteli, 2002). As a consequence, it could be difficult to distinguish signals emitted by the chromosome pair due to their close position. Anyway, even if these artifacts may have been included in our analysis, this would have concerned all the experimental groups in the same extent. It could not explain the differences observed between the groups. The level of aneuploid nuclei remained significantly higher in embryo from diuron-exposed genitors that is concordant with the other results on DNA damage obtained by FCM in spat from the same experiment (Barranger et al., 2014).

The selected diuron concentrations were realistic with regards to data available in the literature and corresponded to medium concentrations in the natural environment. In this study, nominal diuron concentrations targeted for our study were 0.4 and $0.6 \mu \mathrm{g} / \mathrm{L}$. However, Polar Organic Chemical Integrative Samplers (POCIS) installed in rearing structures, highlighted effective exposure concentrations of only 0.2 and $0.3 \mu \mathrm{g} / \mathrm{L}$. In comparison to the regulatory Annual Average-Environmental Quality Standards and Maximum Allowable ConcentrationEnvironmental Quality Standards (AA-EQS $=0.2 \mu \mathrm{g} / \mathrm{L}$ and MAC-EQS $=1.8 \mu \mathrm{g} / \mathrm{L}$ ) for diuron defined by the EU Water Framework Directive (EU, 2013), the results obtained with these concentrations were highly worrisome from an environmental viewpoint as negative effects were observed at a lower concentration than the MAC-EQS and for a short-term exposure duration.

\section{CONCLUSION}

For the first time, our study demonstrated the presence of aneuploid C. gigas embryos following parental diuron exposure using FISH. 5S and 18-5.8-28S rDNA genes, located on 
chromosomes 4, 5 and 10, were found to be regions impacted by DNA loss. The origin of this aneuploidy remains to be determined, in particular through the study of germ cells. The persistence of these missing regions should also be examined in terms of embryo survival at juvenile/adult stages. Finally, the vertical transmission of DNA damage was observed at low environmental concentrations, hence highlighting the importance of water quality for population fitness of a species with such major economic weight as the Pacific oyster. 


\section{ACKNOWLEDGMENTS}

This work was funded by the French National Research Agency (ANR-CESA-01601). The authors wish to thank all the people in charge of the hatchery at Ifremer La Tremblade.

\section{REFERENCES}

Aardema, M.J., Albertini, S., Arni, P., Henderson, L.M., Kirsch-Volders, M., Mackay, J.M., Sarrif, A.M., Stringer, D.A., Taalman, R.D., 1998. Aneuploidy: a report of an ECETOC task force. Mutat. Res. 410, 3-79.

Abruzzo, M.A., Hassold, T.J., 1995. Etiology of nondisjunction in humans. Environ. Mol. Mutagen. 25, 38-47. doi:10.1002/em.2850250608

Akcha, F., Spagnol, C., Rouxel, J., 2012. Genotoxicity of diuron and glyphosate in oyster spermatozoa and embryos. Aquat. Toxicol. 106-107, 104-113. doi:10.1016/j.aquatox.2011.10.018

Barranger, A., Akcha, F., Rouxel, J., Brizard, R., Maurouard, E., Pallud, M., Menard, D., Tapie, N., Budzinski, H., Burgeot, T., Benabdelmouna, A., 2014. Study of genetic damage in the Japanese oyster induced by an environmentally-relevant exposure to diuron: Evidence of vertical transmission of DNA damage. Aquat. Toxicol. 146, 93-104. doi:10.1016/j.aquatox.2013.10.032

Benabdelmouna, A., Abirached-Darmency, M., 1997. Distribution and chromosomal organization of 18S-5.8S-25S and 5S rDNA in Petunia species. Agronomie 17, 349-360.

Benabdelmouna, A., Nadolna, K., Ledu, C., 2008. Fluorescence in situ hybridization (FISH) of rDNA genes (5S and 18-5.8-28S) as a tool for chromosomal tagging and to assess the occurrence of somatic and sperm aneuploidy in Pacific oyster Crassostrea gigas. XVI Plant \& Animal Genome Conference (PAG).

Benabdelmouna, A., Ollier, S., Maurouard, E., D’Amico, F., Seugnet, J.L., Grizon, J., 2011. Niveau de ploïdie des naissains d'huître creuse captés dans les bassins de Marennes Oléron, Baie de Bourgneuf et Arcachon. Réseau Biovigilance, campagne 2011 http://archimer.ifremer.fr/doc/00107/21837/.

Berthelin, C.H., Laisney, J., Espinosa, J., Martin, O., Hernandez, G., Mathieu, M., Kellner, K., 2001. Storage and reproductive strategy in Crassostrea gigas from two different growing areas (Normandy and the Atlantic coast, France). Invertebr. Reprod. Dev. 40, 79-86.

Bihari, N., Mičić, M., Batel, R., Zahn, R.K., 2003. Flow cytometric detection of DNA cell cycle alterations in hemocytes of mussels (Mytilus galloprovincialis) off the Adriatic coast, Croatia. Aquat. Toxicol. 64, 121-129. doi:10.1016/S0166-445X(03)00040-7 
Bouilly, K., 2004. Impact de facteurs environnementaux sur l'aneuploïdie chez l'huître creuse, Crassostrea gigas, dans le bassin de Marennes-Oléron. Sci. York. Université de la Rochelle.

Boyd, M.T., Vlatkovic, N., Rubbi, C.P., 2011. The nucleolus directly regulates p53 export and degradation. J. Cell Biol. 194, 689-703. doi:10.1083/jcb.201105143

Buisson, S., Bouchart, V., Guerlet, E., Malas, J.P., Costil, K., 2008. Level of contamination and impact of pesticides in cupped oyster, Crassostrea gigas, reared in a shellfish production area in Normandy (France). J. Environ. Sci. Health. B. 43, 655-64. doi:10.1080/03601230802352732

Burgeot, T., Gagnaire, B., Renault, T., Haure, J., Moraga, D., David, E., Boutet, I., Sauriau, P.G., Malet, N., Bouchet, V., Le Roux, A., Lapègue, S., Bouilly, K., Le Moullac, G., Arzul, G., Knoery, J., Quiniou, F., Bacher, C., Soletchnick, P., 2008. Oyster summer morality risks associated with environmental stress., in: Samain, J.F., McCom- Bie, H. (Eds.), Summer Mortality of Pacific Oyster Crassostrea Gigas. The Morest Project. Éd. Ifremer/Quæ. pp. $107-151$.

Caquet, T., Roucaute, M., Mazzella, N., Delmas, F., Madigou, C., Farcy, E., Burgeot, T., Allenou, J.-P., Gabellec, R., 2013. Risk assessment of herbicides and booster biocides along estuarine continuums in the Bay of Vilaine area (Brittany, France). Environ. Sci. Pollut. Res. 20, 651-666.

Cross, I., Díaz, E., Sánchez, I., Rebordinos, L., 2005. Molecular and cytogenetic characterization of Crassostrea angulata chromosomes. Aquaculture 247, 135-144. doi:10.1016/j.aquaculture.2005.02.039

Dallas, L.J., Bean, T.P., Turner, A., Lyons, B.P., Jha, A.N., 2013. Oxidative DNA damage may not mediate Ni-induced genotoxicity in marine mussels: assessment of genotoxic biomarkers and transcriptional responses of key stress genes. Mutat. Res. 754, 22-31. doi:10.1016/j.mrgentox.2013.03.009

Dégremont, L., Boudry, P., Ropert, M., Samain, J.-F., Bédier, E., Soletchnik, P., 2010. Effects of age and environment on survival of summer mortality by two selected groups of the Pacific oyster Crassostrea gigas. Aquaculture 299, 44-50. doi:10.1016/j.aquaculture.2009.12.009

Dixon, D.R., 1982. Aneuploidy in Mussel embryos (Mytilus Edulis L.) originating from a polluted dock. Mar. Biol. Lett. 3, 155-161.

Elkholi, R., Chipuk, J.E., 2014. How do i kill thee ? Let me count the ways: p53 regulates PARP1 dependent necrosis. Bioessays 36, 46-51. doi:10.1002/bies.201300117.How

EU, 2013. DIRECTIVE 2013/39/EU OF THE EUROPEAN PARLIAMENT AND OF THE COUNCIL of 12 August 2013 amending Directives 2000/60/EC and 2008/105/EC as regards priority substances in the field of water policy. Off. J. Eur. Union. 
Fankhauser, G., 1945. The Effects of Changes in Chromosome Number on Amphibian Development. Q. Rev. Biol. 20, 20-78. doi:10.2307/2809003

FAO, 2012. Global Aquaculture Production 1950-2012 -

http://www.fao.org/fishery/statistics/global-aquaculture-production/en [WWW Document].

Ferguson, K. a, Wong, E.C., Chow, V., Nigro, M., Ma, S., 2007. Abnormal meiotic recombination in infertile men and its association with sperm aneuploidy. Hum. Mol. Genet. 16, 2870-9. doi:10.1093/hmg/ddm246

FitzPatrick, D.R., Ramsay, J., McGill, N.I., Shade, M., Carothers, A.D., Hastie, N.D., 2002. Transcriptome analysis of human autosomal trisomy. Hum. Mol. Genet. 11, 3249-56.

Fontana, F., Lanfredi, M., Congiu, L., Leis, M., Chicca, M., Rossi, R., 2003. Chromosomal mapping of 18S--28S and 5S rRNA genes by two-colour fluorescent in situ hybridization in six sturgeon species. Genome 46, 473-477. doi:10.1139/g03-007

Guo, X., Cooper, K., Hershberger, W., Chew, K., 1992. Genetic consequences of blocking polar body I with cytochalasin B in fertilized eggs of the Pacific oyster, Crassostrea gigas: I. Ploidy of resultant embryos. Biol. Bull. 183, 381-386.

Guo, X., Hershberger, W., Cooper, K., Chew, K., 1993. Artificial gynogenesis with ultraviolet light-irradiated sperm in the Pacific oyster, Crassostrea gigas. I. Induction and survival. Aquaculture 113, 201-214.

Hassold, T., Hunt, P., 2001. To err (meiotically) is human: the genesis of human aneuploidy. Nat Rev Genet 2, 280-291.

Huvet, A., Normand, J., Fleury, E., Quillien, V., Fabioux, C., Boudry, P., 2010. Reproductive effort of Pacific oysters: A trait associated with susceptibility to summer mortality. Aquaculture 304, 95-99. doi:10.1016/j.aquaculture.2010.03.022

Insua, A., Freire, R., Ríos, J., Méndez, J., 2001. The 5S rDNA of mussels Mytilus galloprovincialis and M. edulis: sequence variation and chromosomal location. Chromosom. Res. 9, 495-505.

Jacquet, F., Butault, J.-P., Guichard, L., 2011. An economic analysis of the possibility of reducing pesticides in French field crops. Ecol. Econ. 70, 1638-1648. doi:10.1016/j.ecolecon.2011.04.003

Jha, A.N., Cheung, V. V, Foulkes, M.E., Hill, S.J., Depledge, M.H., 2000. Detection of genotoxins in the marine environment: adoption and evaluation of an integrated approach using the embryo-larval stages of the marine mussel, Mytilus edulis. Mutat. Res. 464, 213228. 
Jin, Y.Q., An, G.S., Ni, J.H., Li, S.Y., Jia, H.T., 2014. ATM-dependent E2F1 accumulation in the nucleolus is an indicator of ribosomal stress in early response to DNA damage. Cell Cycle 13, 1627-1638.

Kirkpatrick, G., Ferguson, K.A., Gao, H., Tang, S., Chow, V., Yuen, B.H., Ma, S., 2008. A comparison of sperm aneuploidy rates between infertile men with normal and abnormal karyotypes. Hum. Reprod. 23, 1679-83. doi:10.1093/humrep/den126

Komen, H., Thorgaard, G.H., 2007. Androgenesis, gynogenesis and the production of clones in fishes: A review. Aquaculture 269, 150-173. doi:10.1016/j.aquaculture.2007.05.009

Kops, G.J.P.L., Weaver, B.A.A., Cleveland, D.W., 2005. On the road to cancer: aneuploidy and the mitotic checkpoint. Nat Rev Cancer 5, 773-785.

Leitao, A., Boudry, P., Thiriot-quievreux, C., 2001. Negative correlation between aneuploidy and growth in the Pacific oyster, Crassostrea gigas : ten years of evidence. Aquaculture 193, 39-48.

Leitão, A., Boudry, P., Thiriot-Quiévreux, C., 2001. Evidence of differential chromosome loss in aneuploid karyotypes of the Pacific oyster, Crassostrea gigas. Genome 44, 735-737.

Liu, Z.-L., Zhang, D., Hong, D.-Y., Wang, X.-R., 2003. Chromosomal localization of 5 S and 18S-5.8S-25S ribosomal DNA sites in five Asian pines using fluorescence in situ hybridization. Theor. Appl. Genet. 106, 198-204. doi:10.1007/s00122-002-1024-z

Longo, F.J., 1972. The effects of cytochalasin B on the events of fertilization in the surf clam, Spisula solidissima. I. Polar body formation. J. Exp. Zool. 182, 321-344. doi:10.1002/jez.1401820305

Mai, H., Morin, B., Budzinski, H., Cachot, J., 2013. Environmental concentrations of irgarol, diuron and S-metolachlor induce deleterious effects on gametes and embryos of the Pacific oyster, Crassostrea gigas. Mar. Environ. Res. 89, 1-8. doi:10.1016/j.marenvres.2013.04.003

Marcheselli, M., Azzoni, P., Mauri, M., 2011. Novel antifouling agent-zinc pyrithione: stress induction and genotoxicity to the marine mussel Mytilus galloprovincialis. Aquat. Toxicol. 102, 39-47. doi:10.1016/j.aquatox.2010.12.015

Martins, C., Galetti, P.M., 2001. Two 5S rDNA arrays in neotropical fish species: is it a general rule for fishes? Genetica 111, 439-46.

Meunier-rotival, M., Cortadas, J., Macaya, G., Bernardi, G., 1979. Isolation and organization of calf ribosomal DNA. Nucleic Acids Res. 6, 2109-2123.

Munaron, D., Dubernet, J., Delmas, F., Stanisière, J., Scribe, P., 2006. Assessment of the quantities of herbicides and nutrients brought down by the river Charente to the coast and 
modelling of the dispersion of atrazine in the Marennes-Oléron bay. Cah. Biol. Mar. 47, 8592.

Munaron, D., Scribe, P., Dubernet, J.F., Kantin, R., Vanhoutte, A., Fillon, A., Bacher, C., 2003. Estimation of herbicide inputs in a sensitive area on the Atlantic coast: Marennes-Oleron Bay (France), in: Pesticides in Air, Plant, Soil and Water System. La Goliardica Pavese srl, Proceedings of the XII Symposium Pesticide Chemistry, Piacenza, Italy, 4-6 June 2003, pp. 717-726.

Munaron, D., Tapie, N., Budzinski, H., Andral, B., Gonzalez, J.-L., 2012. Pharmaceuticals, alkylphenols and pesticides in Mediterranean coastal waters: Results from a pilot survey using passive samplers. Estuar. Coast. Shelf Sci. 114, 82-92.

doi:10.1016/j.ecss.2011.09.009

O’Connor, C., 2008. Chromosomal abnormalities: Aneuploidies. Nat. Educ. 1, 172.

Ochoa, V., Riva, C., Faria, M., Köck-Schulmeyer, M., de Alda, M.L., Barceló, D., Fernandez Tejedor, M., Roque, A., Ginebreda, A., Barata, C., 2012. Are pesticide residues associated to rice production affecting oyster production in Delta del Ebro, NE Spain? Sci. Total Environ. 437, 209-18. doi:10.1016/j.scitotenv.2012.07.058

Parada, L., Misteli, T., 2002. Chromosome positioning in the interphase nucleus. Trends Cell Biol. 12, 425-432.

Peaucellier, G., Guerrier, P., Bergerard, J., 1974. Effects of cytochalasin B on meiosis and development of fertilized and activated eggs of Sabellaria alveolata L. (Polychaete Annelid). J. Embryol. Exp. Morphol. 31, 61-74.

Rambags, B.P.B., Krijtenburg, P.J., Drie, H.F. Van, Lazzari, G., Galli, C., Pearson, P.L., Colenbrander, B., Stout, T. a E., 2005. Numerical chromosomal abnormalities in equine embryos produced in vivo and in vitro. Mol. Reprod. Dev. 72, 77-87. doi: $10.1002 / \mathrm{mrd} .20302$

Renault, T., Le Deuff, R.M., Cochennec, N., Maffart, P., 1994. Herpesviruses associated with mortalities among Pacific oyster, Crassostrea gigas, in France - Comparative study. Rev. Médicale Vétérinaire 145, 735-742.

Samain, J.F., Dégremont, L., Soletchnik, P., Haure, J., Bédier, E., Ropert, M., Moal, J., Huvet, A., Bacca, A., Van Wormhoudt, A., Delaporte, M., Costil, K., Pouvreau, S., Lambert, C., Boulo, V., Soudant, P., Nicolas, J.., Le Roux, F., Renault, T., Gagnaire, B., Geret, F., Boutet, I., Burgeot, T., Boudry, P., 2007. Genetically based resistance to summer mortality in the Pacific oyster (Crassostrea gigas) and its relationship with physiological, immunological characteristics and infection processes. Aquaculture 268, 227-243.

Stepto, N.K., Cook, P.A., 1998. Induction of triploidy in the South African abalone using cytochalasin Bull. Aquacult. Int. 6, 161-169. 
Streisinger, G., Walker, C., Dower, N., Knauber, D., Singer, F., 1981. Production of clones of homozygous diploid zebra fish (Brachydanio rerio). Nature 291, 293-296.

Sun, F., Mikhaail-Philips, M., Oliver-Bonet, M., Ko, E., Rademaker, A., Turek, P., Martin, R.H., 2008. The relationship between meiotic recombination in human spermatocytes and aneuploidy in sperm. Hum. Reprod. 23, 1691-7. doi:10.1093/humrep/den027

Thiriot-Quiévreux, C., Pogson, G.H., Zouros, E., 1992. Genetics of growth rate variation in bivalves: aneuploidy and heterozygosity effects in a Crassostrea gigas family. Genome 35, 39-45. doi:10.1139/g92-007

Thomas, K. V, Fileman, T.W., Readman, J.W., Waldock, M.J., 2001. Antifouling Paint Booster Biocides in the UK Coastal Environment and Potential Risks of Biological Effects. Mar. Pollut. Bull. 42, 677-688.

Thorgaard, G.H., Gall, G. a, 1979. Adult triploids in a rainbow trout family. Genetics 93, 96173.

UIPP (Union des industries de la protection des plantes), 2012. Rapport d'activité 2011-2012. http://www.uipp.org/Actualites/Legislation-et-reglementation/Actualite-francaise/Rapportd-activite-UIPP-2011-2012-consultable-en-ligne, 2014.

Viuff, D., Palsgaard, A., Rickords, L., Lawson, L.G., Greve, T., Schmidt, M., Avery, B., Hyttel, P., Thomsen, P.D., 2002. Bovine embryos contain a higher proportion of polyploid cells in the trophectoderm than in the embryonic disc. Mol. Reprod. Dev. 62, 483-8. doi: $10.1002 / \mathrm{mrd} .90004$

Vorsanova, S.G., Yurov, Y.B., Iourov, I.Y., 2010. Human interphase chromosomes: a review of available molecular cytogenetic technologies. Mol. Cytogenet. 3, 1-15. doi:10.1186/17558166-3-1

Wang, Y., Xu, Z., Guo, X., 2004. Differences in the rDNA-bearing chromosome divide the Asian-Pacific and Atlantic species of Crassostrea (Bivalvia, Mollusca). Biol. Bull. 206, 4654.

Weaver, B.A., Cleveland, D.W., 2006. Does aneuploidy cause cancer? Curr. Opin. Cell Biol. 18, 658-67. doi:10.1016/j.ceb.2006.10.002

Wessel, N., Rousseau, S., Caisey, X., Quiniou, F., Akcha, F., 2007. Investigating the relationship between embryotoxic and genotoxic effects of benzo[a]pyrene, 17alpha-ethinylestradiol and endosulfan on Crassostrea gigas embryos. Aquat. Toxicol. 85, 133-42.

doi:10.1016/j.aquatox.2007.08.007

Xu, Z., Guo, X., Gaffney, P.M., Pierce, J.C., 2001. Chromosomal location of the Major Ribosomal RNA Genes in Crassostrea virginica and Crassostrea gigas. The Veliger 44, 7983. 
Zouros, E., Thiriot-Quievreux, C., Kotoulas, G., 1996. The negative correlation between somatic aneuploidy and growth in the oyster Crassostrea gigas and implications for the effects of induced polyploidization. Genet. Res. 68, 109-116. doi:10.1017/S0016672300033991

Zudova, D., Rezacova, O., Kubickova, S., Rubes, J., 2003. Aneuploidy detection in porcine embryos using fluorescent in situ hybridization. Cytogenet. Genome Res. 102, 179-183. 


\section{Table Legend}

Table 1. Results of FISH analysis of embryo nuclei from the various experimental groups. 


\section{Figure Legend}

Figure 1. Two-color I-FISH with rDNA probes. Representative images of normal and aneuploid $C$. gigas embryo nuclei with rDNA genes identified by fluorescent in situ hybridization. (A) Normal, diploid nucleus (stained blue) from a control embryo with chromosomes 4 and 5 (green probe) and chromosome 10 (red probe). (C, D, E, F, G, H, I, J, K) Examples of hypodiploid nuclei. (B, L) Examples of hyperdiploid nuclei. (L) Triploid nucleus. 


\begin{tabular}{|c|c|c|c|c|c|}
\hline \multirow{2}{*}{\multicolumn{3}{|c|}{ FISH probe combinations }} & \multicolumn{3}{|c|}{ Percentage (number) of embryo nuclei } \\
\hline & & & \multirow{2}{*}{$\begin{array}{c}\begin{array}{c}\text { Seawater } \\
\text { control }\end{array} \\
89.53(633)\end{array}$} & \multirow{2}{*}{$\begin{array}{c}\begin{array}{c}\text { Solvent } \\
\text { exposed }\end{array} \\
86.10(613)\end{array}$} & \multirow{2}{*}{$\begin{array}{c}\begin{array}{c}\text { Diuron } \\
\text { exposed }\end{array} \\
69.34(459)\end{array}$} \\
\hline & loid & $\cdots \cdots \bullet$ & & & \\
\hline \multirow{15}{*}{$\begin{array}{l}\frac{0}{0} \\
\frac{0}{2} \\
\frac{\pi}{0} \\
\frac{1}{4}\end{array}$} & \multirow{10}{*}{ Hypodiploid } & $\cdots \bullet \bullet$ & $2.97(21)$ & $2.95(21)$ & $4.68(31)$ \\
\hline & & $\cdots \cdots$ & $0.28(2)$ & 0 & $1.21(8)$ \\
\hline & & $\bullet \bullet \bullet$ & $3.11(22)$ & $2.67(19)$ & $7.10(47)$ \\
\hline & & $\cdots \bullet$ & 0 & 0 & $1.51(10)$ \\
\hline & & $\cdots \cdots$ & 0 & 0 & $0.3(2)$ \\
\hline & & $\cdots \cdots$ & $0.28(2)$ & $0.14(1)$ & $1.06(7)$ \\
\hline & & $\bullet$ & 0 & 0 & $0.3(2)$ \\
\hline & & $\cdots$ & 0 & 0 & $0.91(6)$ \\
\hline & & $\bullet$ & 0 & 0 & $0.45(3)$ \\
\hline & & $\bullet$ & 0 & 0 & $0.3(2)$ \\
\hline & \multicolumn{2}{|c|}{ Total } & $6.64(47)$ & $5.76(41)$ & $17.82(118)$ \\
\hline & \multirow{3}{*}{ Hyperdiploid } & $\bullet \bullet$ & $0.71(5)$ & $0.98(7)$ & $1.36(9)$ \\
\hline & & $\bullet \bullet \bullet \bullet \bullet \bullet \bullet$ & 057 (1) & $205(21)$ & 300 (מ) 30 \\
\hline & & Triploid & & & \\
\hline & \multicolumn{2}{|c|}{ Total } & $1.28(9)$ & $3.93(28)$ & $4.38(29)$ \\
\hline \multicolumn{2}{|c|}{ Haploid (Hypodiploid) } & $\cdots \bullet$ & $2.55(18)$ & $4.21(30)$ & $8.46(56)$ \\
\hline
\end{tabular}




\section{Highlights}

- $\quad$ FISH was realized on oyster embryos from diuron-exposed genitors.

- rDNA genes were used as probes on the interphase nuclei of embryo preparations.

- Higher aneuploidy level was observed in embryos from diuron-exposed genitors.

- Hypo- and hyperdiploid (triploid) nuclei were detected. 

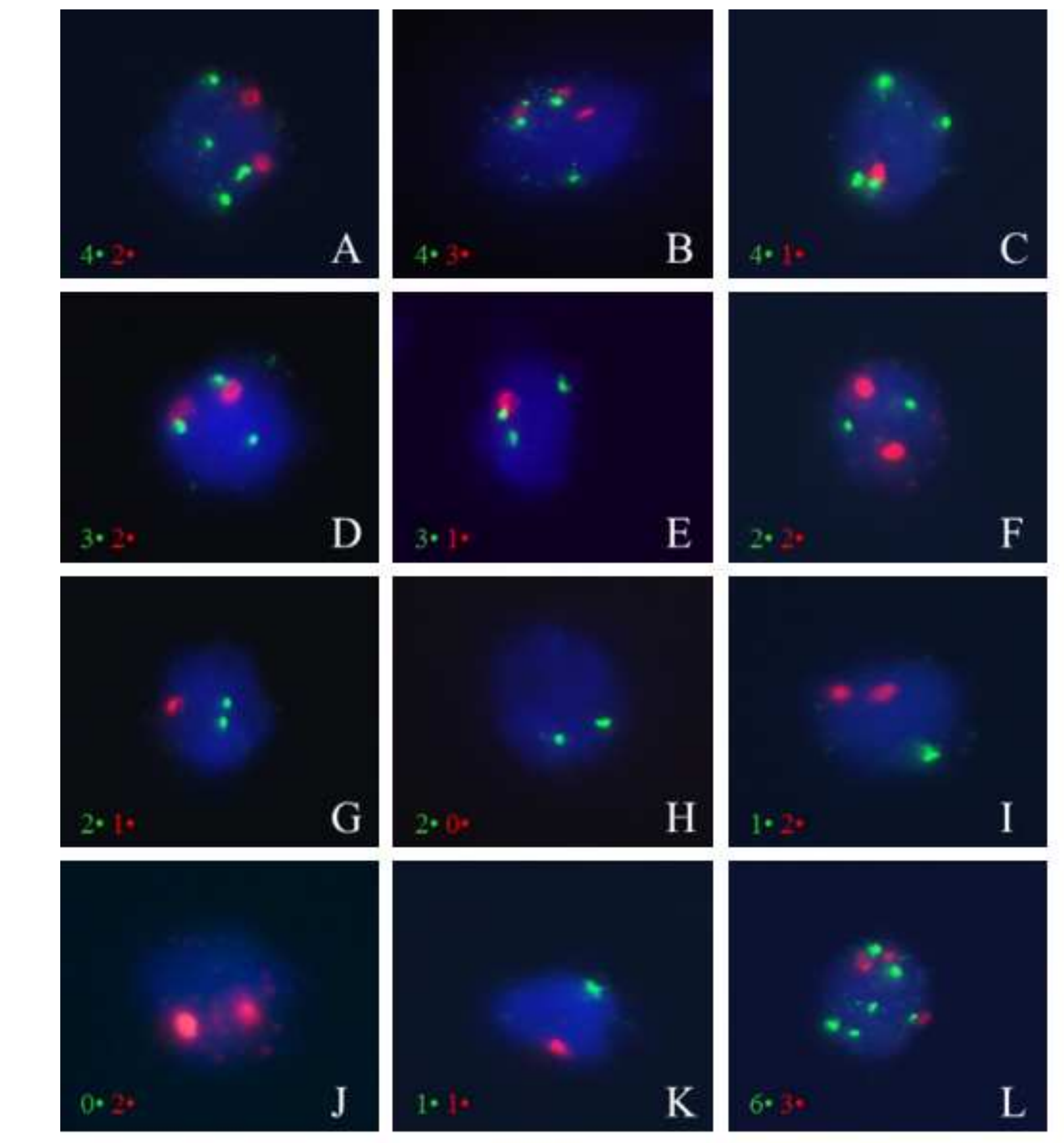

Page 29 of 29

Page 29 of 29

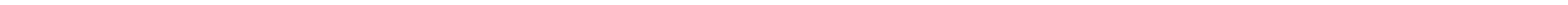

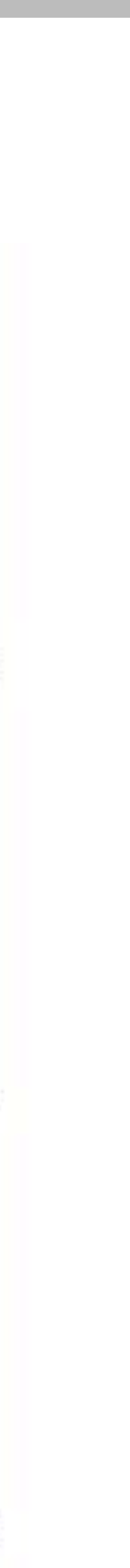

